\title{
HOXD13 wt Allele
}

National Cancer Institute

\section{Source}

National Cancer Institute. HOXD13 wt Allele. NCI Thesaurus. Code C97584.

Human HOXD13 wild-type allele is located in the vicinity of 2 q31.1 and is approximately 3 $\mathrm{kb}$ in leng th. This allele, which encodes homeobox protein Hox-D13, is involved in transcriptional regulation. Mutation of the gene is associated with congenital limb and appendage abnormalities and VACT ERL (vertebral anomalies, anal atresia, congenital cardiac disease, tracheoesophageal fistula, renal anomalies, radial dysplasia, and other limb defects). 